\title{
Parking, People, and Cities
}

\author{
Michael Manville ${ }^{1}$ and Donald Shoup ${ }^{2}$
}

\begin{abstract}
In this study of how off-street parking requirements affect urban form, we begin by analyzing the relationship between population density and streets in cities. We find that denser cities devote a greater share of their land to streets, but also have less street space per person. This relationship results in part from the difficulty of constructing new streets in built-out areas. The amount of street space does not increase as fast as population density, and this in turn helps explain why dense areas have less vehicle travel per person but higher levels of congestion. In contrast to streets, new off-street parking is supplied continually, owing largely to minimum parking requirements that make new development contingent on the provision of parking spaces. But the ample supply of off-street parking makes traffic congestion worse and inhibits street life. We recommend either removing off-street parking requirements, or converting them from minimums to maximums.
\end{abstract}

DOI: 10.1061/(ASCE)0733-9488(2005)131:4(233)

CE Database subject headings: Parking facilities; Streets; Zoning; Regulations; Traffic congestion.

\section{Introduction}

What man had rather were true he more readily believes. Francis Bacon

Parking requirements in zoning ordinances are an understudied link between the automobile and urban form. Parking spaces themselves are ubiquitous (we notice them most when they are absent), and they are ubiquitous in part because cities require parking almost everywhere. In an age that gives increasing attention to market-oriented solutions for public policy problems, parking remains heavily regulated, with its supply mandated by zoning-enforced minimums. Off-street parking is often deadening, dull, and hostile to pedestrians, and is provided at the expense of other, more productive investments. Where density is low parking is land intensive, and where density is high it is capital intensive, making its cost substantial in both places. Most of all, the mandated provision of parking tacitly subsidizes automobile ownership. Most cars are parked most of the time, and both auto use and auto ownership are easier if a car can be cheaply and reliably stored when it is not being driven. Traffic congestion rightly earns tremendous attention, but the less glamorous parked car shapes daily urban life as much, if not more, than the car inching forward on a crowded freeway.

Our approach is to compare the supply of off-street parking with the supply of streets. We first examine the interaction between street space and population density. Dense areas devote a

\footnotetext{
${ }^{1}$ Dept. of Urban Planning, Univ. of California, Los Angeles, CA 90095.

${ }^{2}$ Dept. of Urban Planning, Univ. of California, Los Angeles, CA 90095.

Note. Discussion open until May 1, 2006. Separate discussions must be submitted for individual papers. To extend the closing date by one month, a written request must be filed with the ASCE Managing Editor. The manuscript for this paper was submitted for review and possible publication on November 10, 2004; approved on February 15, 2005. This paper is part of the Journal of Urban Planning and Development, Vol. 131, No. 4, December 1, 2005. CASCE, ISSN 0733-9488/2005/4-233$245 / \$ 25.00$.
}

greater share of their land to streets, but also have less street space per capita. In places where most people drive, this fuels urban congestion, because street lane mileage cannot be increased as rapidly as increases in people, who bring with them increases in vehicle miles traveled. Minimum parking requirements, however, force the supply of parking to keep pace with new development. The space available to park cars thus rises much faster than the space available for them to drive. This asymmetry between streets and parking makes congestion worse and undermines one of density's great benefits—vibrant street life.

\section{Professional and Academic Neglect of Parking}

Despite its strong influences on cities and people, parking is often ignored in studies of travel patterns. When people think of travel they generally think of the act of traveling, and the iconography of the car is more strongly associated with streets and freeways than with parking structures. This bias extends to many academic considerations of travel; travel models emphasize the car so long as it is being driven, but at journey's end the car simply vaporizes, and the costs of storing it are disregarded. The parking lot is where we stop thinking about the car, because parking means we have reached our destination; it is where the driver becomes a pedestrian. For the car, however, the parking lot is the destination, and the parked car takes up more room than the person walking away from it.

Planning professionals usually consider parking only as an appendage to a building; rarely are the costs and benefits of parking considered on their own-even in cases where the parking dwarfs the building itself. It would be more appropriate to examine a building and its parking lot separately, but parking requirements often make the building conditional on the parking. There is no question about whether the building might be better without its parking spaces; without its parking spaces there is no building. As William Fulton (2001) has observed, off-street parking requirements demand that developers first build a parking lot, and then get permission from the city to build something that will finance the parking lot.

Academics and activists concerned about the car's impact on 
the landscape also tend not to consider parking on its own, and instead often aggregate it together with streets. They do so for a number of reasons. Both parking lots and streets are often paved areas, and all paved areas share certain characteristics, particularly with regard to environmental effects like runoff. Streets and parking lots are also both automobile infrastructure, and in this sense it may be appropriate to consider them together. Finally there is an advocacy issue. If one wants to make a point about the amount of land consumed by the car (and if one's point is that it is excessive), it helps to have the biggest number possible. As we show in the next section, rolling streets and parking into one aggregate figure can generate an alarming, eye-catching statistic.

At the same time, however, combining street space and parking space into one number can obscure important relationships between transportation and land use. Streets and parking have different purposes, are provided in different ways, and interact differently with people. Streets are automobile infrastructure, but not exclusively so; the street long predated the car, and even today streets are used for many activities other than driving. Parking, however, is entirely a product of the car culture. Most streets are publicly owned, while most off-street parking is privately owned but publicly required. Most important, the supply of streets is relatively fixed, particularly in built-out areas, and in such areas street space increases only marginally even as population rises or land is redeveloped-a dynamic that contributes mightily to traffic congestion. Parking has in many ways a more expandable supply, owing to the zoning ordinances that force it to move in sync with new development. Thus while streets in dense cities are often considered to be in undersupply, parking is often in oversupply.

In this paper we highlight the impact that parking requirements have on urban areas, and particularly on downtowns. As an empirical example we focus on Los Angeles, which has often been a target of criticism from people who believe the car has corrupted American urban form. Although many people agree that Los Angeles (LA) is poorly planned, explanations of why it is poorly planned tend to be elusive. The city has been called an archetype of sprawl, but its central city density is rather high for an American city, and its total urbanized area is the densest in the United States. The LA region also ranks rather low in terms of per capita vehicle ownership (Ewing 1997; Sierra Club 1998; McGuckin and Srinivasan 2003). The region does, however, devote a tremendous amount of space to parking. We suspect that what is emerging in LA is a car-oriented density, a condition fostered by the city's minimum parking requirements. Because parking requirements are essentially automobile subsidies that are yoked to new development, they offset many of the benefits of increased density.

We are not arguing a one-way causal process. Parking requirements alone did not create automobile dependency. As we will show in the article (and as many others have shown before us), the accidents of history also play a strong role in the way cities develop. But parking requirements have often formalized land use patterns that might otherwise have been impermanent, and they have channeled an enormous amount of money and land toward the car. Some of that money and land might have been put to better use. Even if parking requirements are not repealed (and we would argue they should be) they certainly deserve to be revisited.

\section{Share of Land Devoted to the Car in Los Angeles}

"In the urban United States, the automobile consumes close to half of the land area of cities; in Los Angeles the figure approaches two-thirds." So says a 1996 book by two Berkeley academics. An interesting fact, to be sure-but how did they know this? They cited a 1992 article by a Berkeley colleague, who said, "In U.S. cities, close to half of all urban area goes to accommodating the automobile, while in Los Angeles the figure reaches two-thirds." Fair enough. But how did he know this? He cited a Washington think tank's 1988 publication, which said, "In American cities, close to half of all the urban space goes to accommodate the automobile; in Los Angeles, the figure reaches twothirds." And where did this come from? It came from a 1980 book by a New Yorker named Kirkpatrick Sale-a self-described neoLuddite-who wrote, "It [the car] demands enormous amounts of space, both in the countryside, where it has so far caused 60,000 square miles of land to be paved over, and in the cities, where roughly half of all the land (in Los Angeles 62\%) is given over to its needs." It is hard to say how Kirkpatrick Sale knew this, because he did not cite a source, and he has not responded to repeated telephone calls asking him for one [see Southworth and Ben-Joseph (1996, pp. 4 and 5); Hanson (1992, p. 66); Renner (1988, p. 46); and Sale (1980, p. 253)].

A fact that lacks documentation is not necessarily wrong; it simply lacks documentation. And the authors above are far from alone in their assumption that Los Angeles gives an inordinate share of its land to the car. Many prominent observers of the city have made similar assertions. Mike Davis (1998, p. 80) asserted that the car had "consumed" more than one-third of the Los Angeles region, by which he meant that a third of the region could be accounted for by streets, driveways, parking lots, and freeways. Roger Keil (1999) said that half of Los Angeles was "used by traffic," also defined as freeways, streets, and parking lots. But many of these claims, when followed back to their sources, seem to have no sources at all. Davis cited a book by Donald Coates (1972, p. 273), who gave no evidence or attribution for his numbers, and who even had a different definition of land "consumed by the car." Keil used Marchand (1986) as a source, but Marchand also offered no evidence to substantiate his claim.

Much of this statistic peddling may originate with Lewis Mumford (1961, p. 510), who in The City in History called Los Angeles the "reductio ad absurdum" of the cult of the car-a city hijacked, to his mind, by the false promises of the motor age. In its eagerness to accommodate the automobile, Mumford said, Los Angeles had given over one-third of its land to the freeway system, and two-thirds of its central business district to streets, freeways, parking facilities, garages. "This," he wrote, "is spaceeating with a vengeance."

Yet Mumford, like those who came after him, did not document his contention; neither a footnote nor a bibliographical reference accompanies it. Nevertheless, his two-thirds figure about the Central Business District (CBD) seems plausible (the other idea, that freeways occupy a third of Los Angeles, is absurd), and there may even be a source for it. Although it is not listed in The City in History's bibliography, in 1959 Seymour Taylor (1959) wrote an article for Traffic Quarterly, which said:

Approximately $28 \%$ of the land area comprising downtown Los Angeles ... is in street, freeway, and service ways and another $38 \%$ is in the off-street vehicular parking and loading, so about two thirds of the land is primarily devoted to rubber. 
Taylor also failed to buttress his case with sources or evidence, but he was General Manager of LA's Department of Traffic, so perhaps he knew what he was talking about. His figures were later reinforced by the consulting firm Wilbur Smith \& Associates (1966), which in “Transportation and parking for tomorrow's cities" concluded that $59 \%$ of the LA CBD was paved area, consisting of sidewalks $(10 \%)$, streets $(25 \%)$, and parking $(24 \%)$. To be sure, the Wilbur Smith report came out too late to be a source for either Mumford or Taylor-and the Smith report, unlike Taylor, makes no mention of freeways - but its numbers do suggest that two-thirds of LA's downtown was devoted to auto-oriented land uses in the 1960s.

Excavating these figures leaves us with an array of not entirely consistent statistics. Obviously the numbers are interesting, and it would be nice to know if they are true. If they are not true (and at least some of them have to be wrong), it might be useful to determine how they floated unquestioned into the middle of academic discourse in the 1990s. Our guess is that the answer lies in what Joel Best (2001) calls "number laundering"- the process by which a statistic gets repeated and then mutates into something else altogether, a new number that is both inaccurate and seems to spring from nowhere. Although we cannot be sure, we suspect that over time Taylor's original statement about downtown LAwhich is itself impossible to confirm-gradually became a series of different statements about the entire Los Angeles region.

But let us assume, for a moment, that some of the numbers are correct. What, exactly, would they tell us? Certainly their implication is pejorative: Mumford was appalled by Los Angeles, and Davis and Keil are also highly critical of it; their assertions about automobiles and land use come amid a larger avalanche of unflattering statements about the region. However, a simple aggregate figure for auto-oriented land uses may not tell us very much-and depending on our initial assumptions, it may lead us to conclusions that are incorrect. Does a high proportion of car-oriented land uses automatically indicate an auto-dependent city? More important, if over two-thirds of LA is taken up by freeways, streets, and parking lots, does it matter what share of that twothirds is accounted for by each one? Does a great deal of land in parking, for example, have the same causes and consequences as a great deal of land in freeways or streets?

Let us look again at Taylor's statistics for downtown Los Angeles. If what he argued was correct, then it was not streets $(28 \%)$ that dominated the LA CBD, but off-street parking (38\%). In fact, by his count off-street parking lots took up more space than any other downtown land use. One could construe this as a sign of the LA CBD's heavy automobile dependency, but that conclusion may be overly simple, as it fails to account for historical circumstances. Taylor was writing in the late 1950s. Downtown LA was slow to recover from the Great Depression, and the lean years of the 1930s and 1940s led a number of property owners to demolish their structures and convert their land to parking lots in order to avoid paying property taxes (Berehndt 1940; Jakle and Sculle 2004). This regrettable process was compounded by the start of an urban renewal program in 1949, which led to the demolition of still more buildings in the northern area of the CBD (known as Bunker Hill). Until the city's redevelopment agency assembled the funding it needed to begin Bunker Hill's reconstruction, much of the land there was used for parking. From 1930 to 1960 the floor area of buildings in the Los Angeles CBD grew by about 1 million square feet, or 3\%; off-street parking, however, grew by 2.5 million square feet, or 203\%. Between 1956 and 1961, a full $55 \%$ of the new parking spaces in downtown LA were the result of buildings being demolished (Smith 1965, pp. 76 and 133).
Thus, by the time Taylor wrote his article a sizeable portion of downtown Los Angeles may well have been parking lots, but many of these lots probably stemmed from property-tax avoidance and urban renewal, rather than any unique affinity for the car.

It is difficult to determine how much land in a given region is devoted to the automobile, let alone understand how such patterns came to be. Despite the freely quoted data about the share of land given to cars, serious attempts to ascertain the surface composition of U.S. cities have been rare, and only recently have researchers in this field begun to use methodology that is reliable. Often these methods include aerial photography. Consider some of the attempts at determining the surface composition of Sacramento, Calif.; in 1972 agricultural engineers L.O. Myrup and D.L. Morgan (1972) used a combination of aerial photos, city engineering records, and parks plans to calculate that $14 \%$ of the Sacramento area was streets (including curbs and sidewalks) and $22 \%$ was "other impervious surfaces"-defined as parking lots, airport runways, and highway shoulder strips. By this measure roughly one-third of Sacramento was paved, and not all the paved areas were exclusively or predominantly for cars.

In 1998 the environmental horticulturalist E.G. McPherson (1998) also used aerial photos to analyze Sacramento, and found that in low-density residential areas paved surfaces accounted for $27 \%$ of the land, while in industrial areas the figure was $50 \%$. Most recently Hashem Akbari, an expert on urban climates at the Berkeley National Laboratory, led an experiment that used highresolution digital photos to estimate ground cover composition in the city (Akbari et al. 2003). Akbari and his colleagues estimated that $41 \%$ of downtown Sacramento was paved surfaces, residential areas were $35 \%$ pavement, and industrial areas ranged between 29 and 44\%. But the researchers could only make this estimate using precision photography, chartered airplanes flying in cloudless skies, and refined methods for estimating the composition of land obscured by trees, awnings, and shadows.

To our knowledge no such aerial analysis has been done on Los Angeles, perhaps because the city is so dauntingly large-or perhaps because, unlike Sacramento, Los Angeles does not have a large urban forest that natural scientists feel compelled to monitor. Thus, most region-wide estimates of the percentage of land given over to the automobile in LA are simply guesses. If any of them are correct, it is more likely the result of a happy accident than any sound methodological approach.

\section{Urban Land in Streets}

In 1997, Stephen Marshall of University College London posted a message on the Internet; in it he mentioned the Berkeley professors' statement that two-thirds of LA's land was consumed by cars, and he asked for similar information about other cities. He summarized the responses and posted them on a web site. Among them was this, from a planner in Australia:

The glib citing of such 'data' is nonsense, of course. Many years ago, as a planning student, I tried to calculate the figure for Melbourne - and found that in older areas of Melbourne (with many wide boulevards and ninety-nine foot local road reserves) the figure was approaching onethird-but that was largely because of the generous precolonial allocation of space to 'streets.' We discovered that the figure for modern suburbs was well below 25 
Table 1. Population Density and the Area of Land in Streets in 1960

\begin{tabular}{|c|c|c|c|c|c|c|}
\hline & \multicolumn{2}{|c|}{$\begin{array}{c}\text { Population } \\
\text { density }\end{array}$} & \multicolumn{2}{|c|}{$\begin{array}{c}\text { Share of } \\
\text { land in streets }\end{array}$} & \multicolumn{2}{|c|}{$\begin{array}{l}\text { Street area } \\
\text { per capita }\end{array}$} \\
\hline & $\begin{array}{l}\text { Persons/ } \\
\text { sq.mile }\end{array}$ & Rank & Percent & Rank & $\begin{array}{l}\text { Square } \\
\text { feet }\end{array}$ & Rank \\
\hline New York & 24,697 & 1 & 30 & 1 & 345 & 14 \\
\hline Newark, N.J. & 17,170 & 2 & 16 & 10 & 257 & 15 \\
\hline San Francisco & 16,559 & 3 & 26 & 2 & 441 & 10 \\
\hline Chicago & 15,836 & 4 & 24 & 4 & 424 & 11 \\
\hline Philadelphia & 15,743 & 5 & 19 & 7 & 365 & 13 \\
\hline St. Louis & 12,296 & 6 & 25 & 3 & 609 & 7 \\
\hline Pittsburgh & 11,171 & 7 & 18 & 8 & 455 & 9 \\
\hline Cleveland & 10,789 & 8 & 17 & 9 & 416 & 12 \\
\hline Miami & 8,529 & 9 & 24 & 5 & 778 & 4 \\
\hline Milwaukee & 8,137 & 10 & 20 & 6 & 724 & 6 \\
\hline Cincinnati & 6,501 & 11 & 13 & 13 & 573 & 8 \\
\hline Los Angeles & 5,451 & 12 & 14 & 12 & 741 & 5 \\
\hline Atlanta & 3,802 & 13 & 15 & 11 & 1,120 & 3 \\
\hline Houston & 2,860 & 14 & 13 & 15 & 1,585 & 1 \\
\hline Dallas & 2,428 & 15 & 13 & 14 & 1,575 & 2 \\
\hline
\end{tabular}

Note: Source=Meyer and Goméz-Ibáñez (1983, p. 181).

percent, suggesting paradoxically that urban areas designed for car use in fact devoted less land to roads and streets.

At first glance this relationship in Melbourne-areas designed for the car devoting less land to streets-may seem counterintuitive, but only because many of us associate streets primarily with cars. We forget that the street long predates the car, and that even streets built after the automobile arrived are rarely the province of cars alone. The assumption that a city oriented to cars will devote a greater share of its land to streets may seem reasonable, but the reality is more complicated.

The Australian planner's study is not the only evidence suggesting a nuanced relationship between cars and land. In their book Autos, Transit and Cities, John Meyer and José GómezIbáñez (1983) used data from the 1960s to examine the relationship between population density and land area in streets for 15 large cities in the United States. Their results reinforce the pattern detected in Melbourne. None of the writers we cited in the previous section made use of the work of Meyer and Gómez-Ibáñez, which is curious. Some of these writers-Mumford among them-were writing before 1968, and for them the data were not available. Although the data were available for later writers, these writers may not have known about it; Meyer and Gómez-Ibáñez devoted only two pages of their 350-page book to the issue of street space and density. (It is also possible, for the more polemical writers, that the Mumford-inspired statistic gave them all the ammunition they needed, and that once they had it they felt no compulsion to question it or look further).

Table 1 shows the results of Meyer and Gómez-Ibáñez (note that these are for cities, not metropolitan statistical or urbanized areas). Columns 1 and 2 show the population density and rank order of each city. New York, at the top with 24,697 persons per square mile, was 10 times denser than Dallas, at the bottom with 2,428 persons per square mile. Columns 3 and 4 show each city's share of land in streets and its rank order. Dense New York used $30 \%$ of its land for streets, while sprawling Dallas used only $13 \%$; the denser cities typically used a larger share of their land for streets (the coefficient of correlation between population density and the share of land in streets was 0.78). But now consider Columns 5 and 6, which show each city's land area in streets per person, and their rank order. Although the denser cities used a larger share of land for streets, they also used less street space per capita (the coefficient of correlation between population density and the street space per capita was -0.89). Low-density Dallas had 1,575 square feet of streets per capita, while compact New York had only 345 square feet per capita. That is, New York's share of land in streets was 2.3 times that of Dallas $(30 \% \div 13 \%)$ but Dallas' street space per capita was 4.6 times that of New York $(1,575 \div 345)$. So which city devotes more land to streets?

Meyer and Gómez-Ibáñez (1983, p. 180) offered an explanation for the inverse relationship between the share of land in streets and the share of land in streets per person:

Automobile use does not result in an exceptional percentage of land being given to transportation purposes. Rather, the automobile seems to create exceptional demands for transportation land relative to the number of people in an urban area. Specifically, cities more dependent on the automobile tend to have more street acreage per person but a smaller percentage of total land in streets.

Population density decreases when people live on larger lots, and this causes the share of land in streets to decline, because the blocks become longer and the lots deeper. Historical studies of city planning lend some credence to this idea. In a study of suburban development patterns in the San Francisco Bay Area, Michael Southworth and Peter Owens (1993) found that the typical grid pattern of 1900 had 28 blocks and 26 intersections per 100 acres, while the looping streets and cul-de-sacs typical of low-density 1980 suburbs had only 8 blocks and 8 intersections per 100 acres. Urban historian James Borchert (1982) observed a similar trend in his study of Washington, D.C.'s alleys in the early 1900s; as automobiles became more prevalent both neighborhood density and the number of alleys declined. The modernist Radiant City designs that became popular in the 1960 s provide a similar contrast. When Century City was built in Los Angeles, its planners called for "wide thoroughfares ... arranged to create large superblocks which avoid excessive streets and alleys." This "city of the freeway age" was designed with just 6 intersections per 100 acres (King 1969).

Low population density reduces the share of land in streets, but also increases the street area per person. Or, to put this another way, where there are few people there are also few streets, but because there are few people each person accounts for a larger share of the street space that exists.

Does this relationship between street space and density still hold? It would be difficult to perfectly replicate the calculations of Meyer and Gómez-Ibáñez. The survey they drew their data from was commissioned under rather extraordinary circumstances - the urban riots and unrest of the 1960s-and similar land use information has not since been regularly collected on central cities. As part of its annual study of urban mobility, however, the Texas Transportation Institute (TTI) collects road information each year from 85 urbanized areas in the United States. Among these data are estimates of each area's lane miles of roads. Dividing a region's total lane miles by its land area gives us its lane-miles per square mile, which should highly correlate with the share of land in streets. Similarly, if we divide total lane mileage by population we get lane-miles per capita, which is roughly equivalent to the category of street space per capita.

For consistency we first used the TTI database to generate numbers for the same panel of cities studied by Meyer and 
Table 2. Population Density and the Share of Land in Streets in 2000

\begin{tabular}{|c|c|c|c|c|c|c|c|c|c|c|}
\hline & $\begin{array}{c}\text { Population } \\
\text { density }\end{array}$ & Rank & $\begin{array}{l}\text { Lane miles } \\
\text { per square mile }\end{array}$ & Rank & $\begin{array}{l}\text { Lane miles per } \\
1,000 \text { persons }\end{array}$ & Rank & $\begin{array}{c}\text { Daily VMT } \\
\text { per square mile }\end{array}$ & Rank & $\begin{array}{l}\text { Daily VMT } \\
\text { per capita }\end{array}$ & Rank \\
\hline Los Angeles & 7,068 & 1 & 7.6 & 1 & 1.4 & 10 & 129,000 & 1 & 23 & 10 \\
\hline San Francisco & 7,004 & 2 & 3.7 & 8 & 1.1 & 17 & 73,000 & 5 & 22 & 13 \\
\hline New York & 5,310 & 3 & 3.5 & 11 & 0.8 & 20 & 68,000 & 6 & 16 & 20 \\
\hline Miami & 4,407 & 4 & 4.3 & 4 & 1.5 & 5 & 61,000 & 8 & 21 & 16 \\
\hline Denver & 3,979 & 5 & 3.3 & 12 & 1.4 & 8 & 54,000 & 15 & 22 & 12 \\
\hline Chicago & 3,914 & 6 & 3.0 & 13 & 1.0 & 19 & 60,000 & 9 & 20 & 17 \\
\hline San Diego & 3,419 & 7 & 4.9 & 2 & 1.3 & 11 & 87,000 & 2 & 24 & 9 \\
\hline Washington D.C. & 3,410 & 8 & 4.3 & 5 & 1.2 & 16 & 83,000 & 3 & 23 & 11 \\
\hline Detroit & 3,094 & 9 & 4.7 & 3 & 1.5 & 2 & 73,000 & 4 & 24 & 8 \\
\hline Baltimore & 3,041 & 10 & 3.9 & 6 & 1.3 & 12 & 66,000 & 7 & 22 & 14 \\
\hline Houston & 2,951 & 11 & 3.0 & 14 & 1.4 & 6 & 55,000 & 14 & 26 & 4 \\
\hline Dallas & 2,946 & 12 & 3.7 & 7 & 1.7 & 1 & 56,000 & 11 & 26 & 5 \\
\hline Philadelphia & 2,862 & 13 & 3.6 & 10 & 1.2 & 15 & 59,000 & 10 & 19 & 19 \\
\hline Phoenix & 2,861 & 14 & 3.7 & 9 & 1.4 & 7 & 55,000 & 13 & 21 & 15 \\
\hline Seattle & 2,844 & 15 & 3.0 & 15 & 1.4 & 9 & 53,000 & 17 & 24 & 7 \\
\hline Minneapolis & 2,671 & 16 & 2.4 & 18 & 1.2 & 14 & 50,000 & 19 & 26 & 6 \\
\hline Tampa Bay, Fla. & 2,571 & 17 & 2.3 & 19 & 1.5 & 3 & 41,000 & 20 & 27 & 3 \\
\hline St. Louis & 2,506 & 18 & 2.8 & 17 & 1.5 & 4 & 53,000 & 16 & 29 & 2 \\
\hline Boston & 2,323 & 19 & 2.9 & 16 & 1.1 & 18 & 52,000 & 18 & 20 & 18 \\
\hline Atlanta & 1,783 & 20 & 2.0 & 20 & 1.2 & 13 & 56,000 & 12 & 34 & 1 \\
\hline
\end{tabular}

Note: Sources $=2000$ U. S. Census and Schrank and Lomax (2004).

Gómez-Ibáñez (with the exception of Newark, which is folded into New York's urban area). Our results indicate that the relationship they identified between density, street space, and streets per capita is still valid. The coefficient of correlation between density and lane-miles per square mile was 0.87 , while the coefficient of correlation between density and lane miles per 1,000 persons was -0.39 . This latter coefficient is weaker than the relationship identified by Meyer and Gómez-Ibáñez, but still negative.

A number of the cities studied by Meyer and Gómez-Ibáñez, however, have lost population since the 1960s. Rust Belt cities like Cincinnati, Milwaukee, and Cleveland are much smaller than they once were, and with the decline of manufacturing employment they no longer rank among America's largest or most important regions. To account for this change, we modified our calculations to include the 20 largest urban areas in the United States. Table 2 shows our results.

The relationships identified by Meyer and Gómez-Ibáñez remain largely unchanged. Substituting new Sun Belt population centers for declining Rust Belt areas does little to alter the interaction between streets and population density. The coefficient of correlation between density and lane miles per square mile remains 0.86 , while the coefficient between density and lane miles per thousand persons is -0.33 . There is some reordering of cities: We list the cities in order of population density, so Los Angeles, as the densest urban area, now sits atop the list. Los Angeles also has the most lane-miles per square mile (7.6) of any urbanized area, and a fairly low, although not the lowest, number of lane miles per 1,000 persons (1.4).

As a final step we ran correlations for the entire TTI database. When all 85 urban areas are taken into account the relationship between density and lane miles per square mile is slightly weaker (0.78), while the relationship between density and per capita lane mileage is slightly stronger $(-0.45)$. In sum, it seems that denser areas still devote a greater share of their land to streets, but have fewer lane miles of street per person.
Given these results, how can we account for the perception that low-density areas give more of their land to streets? Certainly people tend to associate lower density with increased automobile use, and automobile use with streets. The first of these associations, as we have seen, is more complicated than a simple oneway relationship, but the second may increasingly be true. The association between low density and auto-oriented land use, in other words, may lie less in the share of land given over to streets, and more in the share of streets given over to cars.

The modernist street designs identified by Southworth and Owens (1993) consume less total land area than the dense grids that preceded them, but broad boulevards and cul-de-sacs are also streets whose primary purpose-and perhaps sole purpose-is the swift and safe movement of automobiles. The desire in newer areas to accommodate the car has often led to the removal of other uses from roads and streets. Cul-de-sacs, which force more circuitous routes and have a notoriously limited utility for pedestrians, have been promoted. Intersections, which slow traffic or cause it to stop-but which make streets more amenable to walking-have been minimized. Those intersections that get built are made wider, allowing cars to turn with less deceleration but forcing pedestrians to traverse more road space (Southworth and Ben-Joseph 1996).

Where older intersections often have a curb radius of 3-4 ft, newer intersections flare out: It is not uncommon for zoning laws to call for 15 or $20 \mathrm{ft}$ curb radii. The $9 \mathrm{ft}$ travel lanes of older neighborhoods were replaced in newer developments by 11 and $12 \mathrm{ft}$ lanes, and parking lanes are recommended to be wider still, so through traffic will not be unduly slowed when drivers pulled into or out of spaces. In practice, parking lanes rarely reach their recommended widths, but the standards illustrate a new concern with the street as a territory of the car, rather than as an arena for multiple modes and activities. In some places parking lanes have not been widened but instead prohibited entirely; Century City has banished all its parked cars to off-street garages, and reserves its broad streets for moving automobiles. The end effect is the 
same. Because curb parking can help make a street feel more human scaled (by encouraging movement on the sidewalks, and by providing a barrier between pedestrians and fast-moving traffic) its removal can amplify the sense that the street is a facility for cars alone.

\section{Urban Density and Vehicle Miles Traveled}

Columns 4 and 5 of Table 2 show each area's daily vehicle miles traveled (VMT) per square mile, and VMT per capita. Like our figures for lane mileage, these numbers are derived from the TTI's database. Given the relationship we have found between street space and density, it is reasonable to expect that VMT interacts with density in a similar manner. Previous research has shown that traffic volumes correlate highly with density: Ross and Dunning (1997), in a report to the Federal Highway Administration, found that traffic volumes rose at $80 \%$ of the rate of population change. It may be, however, that density and VMT share the same complicated relationship as density and street space.

Our calculations suggest this is so. For the 20 largest urbanized areas, the coefficient of correlation between population density and VMT per square mile is 0.90 , while the coefficient between density and VMT per capita is -0.58 . Los Angeles, the densest area, has the highest daily VMT per square mile $(128,000)$, and by a significant margin. It sits in the middle of the pack in terms of VMT per capita. Using all 85 urban areas weakens the relationship only slightly: the coefficient of correlation between density and VMT per square mile falls to 0.86, and the relationship between density and VMT per capita becomes -0.47 . Increases in population density reduce the VMT per person but increase the VMT per square mile. In low-density areas each person creates more VMT, but because there are fewer people per square mile the VMT per square mile falls. These findings accord well with the idea that sprawl can reduce congestion, but that it also makes for longer trips.

High levels of VMT per square mile suggest high levels of traffic congestion. For this reason it is not surprising that Los Angeles has such a large VMT per square mile, not only because it reinforces the popular perception that LA has the nation's worst traffic, but because the region's relative equality of density (which we discuss in the next section) deprives it of any truly low-density areas that would offer a respite from high congestion levels. We can follow this logic back further into our original seeming paradox: since congestion is properly thought of as competition for scarce road space, areas with high levels of congestion-which is to say dense areas - can be conceived of as lacking in road space, even though they have more of it than less dense areas.

Obviously the problem is not quite that simple. The optimal solution to competition for scarce road space is not more road space, but—as with competition for any scarce resource-prices. In the absence of road pricing, however, it is not uncommon for traffic engineers to state that a congested area has an undersupply of streets. Congestion worsens as population increases because the supply of streets is relatively static, and cannot keep pace with increases in density and VMT if everyone drives everywhere.

\section{Density, the Car and Urban Form}

The positive relationship between density and total VMT can offer us some insight into the traffic problems in Los Angeles. Table 3 shows the population densities of the 20 largest urbanized areas in the United States as well as the 20 largest central cities. Because there is considerable overlap between these categories, only 28 cities are shown. For each place, three measures of density from the 2000 U.S. Census are shown: The density of the central city, the urbanized area, and the suburbs. Looking at urbanized areas (column 3) we see that Los Angeles has the highest population density in the United States, albeit by a nose: It has 7,069 people per square mile in its 1,668 square mile urbanized area, while San Francisco-which ranks second-has 7,004 people per square mile over 428 square miles. San Jose, Calif., is third and New York is fourth. San Jose differs from the other three areas in being much smaller, so we will set it aside for a moment and look at Los Angeles, New York, and San Francisco. Without question, the city of Los Angeles has a lower population density than do the cities of San Francisco and New York (Column 7), but the urbanized area of LA has a higher density than the urbanized areas of the other two.

Los Angeles is renowned for its sprawl, but it is the sprawl of the New York and San Francisco urbanized areas that make them less dense than LA. The Los Angeles urbanized area is denser than that of New York or San Francisco because of its denser suburbs-the urbanized area outside the city of Los Angles (6,431 persons per square mile) is denser than the urbanized areas outside New York (3,211 persons per square mile) and San Francisco $(5,824$ persons per square mile). The density of LA's suburbs is fully 74 percent of that in its central city. In New York and San Francisco, density plummets outside the central city. Suburban New York has only $12 \%$ of the density of its central city, while suburban San Francisco has just 35\%. Los Angeles is a dense city in a very dense region, while New York and San Francisco are very dense cities in less dense regions.

In his study of sprawl in Los Angeles, Eric Eidlin (unpublished manuscript, 2004) compared the population density of Los Angeles with the densities of New York and San Francisco. Eidlin assembled data on a census tract basis for each of three urbanized areas; Fig. 1 shows the distribution of population on the land area in each area. The horizontal axis measures the cumulative share of the urbanized area's population, arrayed according to increasing density. The vertical axis measures the cumulative share of the urbanized area's total population. For Los Angeles, the curve shows less variation in persons per square mile (because people are not heavily concentrated in any one area), while the curves for New York and San Francisco show much steeper differences between the low-density suburbs and the extremely dense central cities (because a much higher proportion of the population in these areas are contained in a much smaller share of land). The New York and San Francisco urbanized areas look like Hong Kong surrounded by Phoenix, while the Los Angeles urbanized area looks like Los Angeles surrounded by ... well, Los Angeles.

We should emphasize that these density differences are not a function of the number of people in each region. Los Angeles does not have more people living in its suburbs than New York. The difference is that New York's suburbanites occupy $154 \%$ more land than LA's, and this makes their population density half that of LA's. Conversely, San Francisco's suburban population is only $29 \%$ that of Los Angeles, but San Francisco suburbanites use $32 \%$ as much land as their LA counterparts, and this makes their density much closer $(91 \%)$ to that of Los Angeles.

Uniform density is not unique to the Los Angeles region. Several regions, among them Memphis, Tenn., Jacksonville, Fla., and Tampa Bay, Fla., have suburban densities greater than $75 \%$ of their central city densities. But these uniform densities are uniformly low. Tampa Bay, the densest of these regions, has only 
Table 3. Population Densities of American Cities in 2000

\begin{tabular}{|c|c|c|c|c|c|c|c|c|c|c|c|c|}
\hline \multirow[b]{2}{*}{$\begin{array}{l}\text { Metropolitan } \\
\text { area }\end{array}$} & \multicolumn{4}{|c|}{ Urbanized area } & \multicolumn{4}{|c|}{ Central city } & \multicolumn{4}{|c|}{ Urbanized area outside central city } \\
\hline & $\begin{array}{c}\text { Population } \\
\text { persons } \\
(1)\end{array}$ & $\begin{array}{c}\text { Land area } \\
\text { sq. miles } \\
\text { (2) }\end{array}$ & $\begin{array}{c}\text { Density } \\
\text { per/sq.mi. } \\
(3)=(1) /(2)\end{array}$ & $\begin{array}{c}\text { Rank } \\
(4)\end{array}$ & $\begin{array}{c}\text { Population } \\
\text { persons } \\
(5)\end{array}$ & $\begin{array}{c}\text { Land area } \\
\text { sq. miles } \\
(6)\end{array}$ & $\begin{array}{c}\text { Density } \\
\text { per/sq.mi. } \\
(7)=(5) /(6)\end{array}$ & $\begin{array}{c}\text { Rank } \\
(8) \\
\end{array}$ & $\begin{array}{l}\text { Population } \\
\text { persons } \\
(9)=(1)-(5)\end{array}$ & $\begin{array}{l}\text { Land area } \\
\text { sq. miles } \\
10=(2)-(6)\end{array}$ & $\begin{array}{c}\begin{array}{c}\text { Density } \\
\text { per/sq.mi. }\end{array} \\
11=(9) /(10)\end{array}$ & $\begin{array}{c}\text { Rank } \\
(12) \\
\end{array}$ \\
\hline Los Angeles & $11,789,487$ & 1,668 & 7,068 & 1 & $3,694,820$ & 420 & 8,797 & 8 & $8,094,667$ & 1,248 & 6,486 & 1 \\
\hline San Francisco & $2,995,769$ & 428 & 7,004 & 2 & 776,733 & 47 & 16,632 & 2 & $2,219,036$ & 381 & 5,824 & 2 \\
\hline San Jose, Calif. & $1,538,312$ & 260 & 5,917 & 3 & 894,188 & 127 & 7,041 & 10 & 644,124 & 133 & 4,843 & 3 \\
\hline New York & $17,799,861$ & 3,353 & 5,309 & 4 & $8,008,278$ & 299 & 26,784 & 1 & $9,791,583$ & 3,054 & 3,207 & 6 \\
\hline Miami & $4,919,036$ & 1,116 & 4,408 & 5 & 362,470 & 35 & 10,356 & 6 & $4,556,566$ & 1,081 & 4,215 & 4 \\
\hline Denver & $1,984,887$ & 499 & 3,978 & 6 & 554,624 & 97 & 5,718 & 16 & $1,430,263$ & 402 & 3,558 & 5 \\
\hline Chicago & $8,307,904$ & 2,123 & 3,913 & 7 & $2,896,016$ & 227 & 12,758 & 3 & $5,411,888$ & 1,896 & 2,854 & 9 \\
\hline Phoenix & $2,907,049$ & 799 & 3,638 & 8 & $1,304,408$ & 298 & 4,377 & 19 & $1,602,641$ & 501 & 3,199 & 7 \\
\hline San Diego & $2,674,436$ & 782 & 3,420 & 9 & $1,218,359$ & 224 & 5,439 & 18 & $1,456,077$ & 558 & 2,609 & 12 \\
\hline Washington, D.C. & $3,933,920$ & 1,157 & 3,400 & 10 & 572,059 & 62 & 9,227 & 7 & $3,361,861$ & 1,095 & 3,070 & 8 \\
\hline San Antonio & $1,327,554$ & 408 & 3,254 & 11 & $1,136,665$ & 317 & 3,586 & 23 & 190,889 & 91 & 2,098 & 20 \\
\hline Detroit & $3,903,377$ & 1,261 & 3,095 & 12 & 951,270 & 139 & 6,844 & 12 & $2,952,107$ & 1,122 & 2,631 & 11 \\
\hline Baltimore & $2,076,354$ & 683 & 3,040 & 13 & 651,154 & 81 & 8,039 & 9 & $1,425,200$ & 602 & 2,367 & 16 \\
\hline Houston & $3,822,509$ & 1,295 & 2,952 & 14 & $1,950,698$ & 499 & 3,909 & 21 & $1,871,811$ & 796 & 2,352 & 17 \\
\hline Dallas & $4,145,659$ & 1,407 & 2,946 & 15 & $1,185,866$ & 288 & 4,118 & 20 & $2,959,793$ & 1,119 & 2,645 & 10 \\
\hline Philadelphia & $5,149,079$ & 1,800 & 2,861 & 16 & $1,517,550$ & 135 & 11,241 & 5 & $3,631,529$ & 1,665 & 2,181 & 19 \\
\hline Columbus, Ohio & $1,133,193$ & 398 & 2,847 & 17 & 710,235 & 183 & 3,881 & 22 & 422,958 & 215 & 1,967 & 22 \\
\hline Seattle & $2,712,205$ & 954 & 2,843 & 18 & 563,374 & 84 & 6,707 & 13 & $2,148,831$ & 870 & 2,470 & 14 \\
\hline Milwaukee & $1,308,913$ & 487 & 2,688 & 19 & 596,974 & 96 & 6,218 & 14 & 711,939 & 391 & 1,821 & 24 \\
\hline Minneapolis & $2,388,593$ & 894 & 2,672 & 20 & 382,618 & 55 & 6,957 & 11 & $2,005,975$ & 839 & 2,391 & 15 \\
\hline Tampa Bay, Fla. & $2,062,339$ & 803 & 2,568 & 21 & 302,401 & 103 & 2,936 & 26 & $1,759,938$ & 700 & 2,514 & 13 \\
\hline St. Louis & $2,077,662$ & 829 & 2,506 & 22 & 348,189 & 62 & 5,616 & 17 & $1,729,473$ & 767 & 2,255 & 18 \\
\hline Memphis, Tenn. & 972,091 & 400 & 2,430 & 23 & 649,449 & 217 & 2,993 & 25 & 322,642 & 183 & 1,763 & 26 \\
\hline Boston & $4,032,484$ & 1,736 & 2,323 & 24 & 589,141 & 47 & 12,535 & 4 & $3,443,343$ & 1,689 & 2,039 & 21 \\
\hline Indianapolis & $1,218,919$ & 553 & 2,204 & 25 & 783,515 & 296 & 2,647 & 27 & 435,404 & 257 & 1,694 & 27 \\
\hline Jacksonville, Fla. & 882,295 & 411 & 2,147 & 26 & 707,338 & 319 & 2,217 & 28 & 174,957 & 92 & 1,902 & 23 \\
\hline Pittsburgh & $1,753,136$ & 852 & 2,058 & 27 & 334,563 & 55 & 6,083 & 15 & $1,418,573$ & 797 & 1,780 & 25 \\
\hline Atlanta & $3,499,840$ & 1,963 & 1,783 & 28 & 416,425 & 132 & 3,155 & 24 & $3,083,415$ & 1,831 & 1,684 & 28 \\
\hline
\end{tabular}

Note: Source $=2000$ U.S. Census, Table GCT-PH1

2,568 people per square mile, as compared to LA's 7,068. The region most similar to Los Angeles is San Jose, Calif., whose urbanized area density is 5,917 people per square mile, and whose suburban density is almost $70 \%$ that of its central city.

The uniform high density of the Los Angeles region has a number of explanations. Doubtless one factor was the postwar shift of population toward the Southeast and Southwest, and the corresponding decline of northeastern and Midwestern urban centers (Glaeser 2003; Mollenkopf 1983; Kantor 1987; Markusen et al. 1991). High levels of immigration have also increased LA's density. For economic reasons, immigrants often live with more people per dwelling unit than do native-born residents; when Fulton et al. (2001) conducted a study on sprawl for the Brookings Institution, they found that the single most important variable in explaining changes of density between 1982 and 1997 was the share of 1990 residents who were foreign born. Los Angeles, as a major immigrant port of entry, ranks near the top of their list of the United States' densest urban areas, and the top 20 are dominated by western urban areas like Phoenix, Modesto, Calif., and Fresno, Calif. Fulton et al. (2001) point as a counterexample to low-density Atlanta, where only 4.1 percent of the residents were foreign born in 1990 .

Last, it is true that for much of the Twentieth Century dense, transit-oriented urban areas declined. Economist Edward Glaeser (2003) has shown that metropolitan density in 1920 is strongly associated with loss of population over the next 40 years (the correlation between initial density and population growth was -0.5). Although there are a number of explanations for this decline (many of the older dense cities are in cold climates, and the invention of air conditioning enabled a shift in growth to warm areas) the primary catalyst Glaeser identified was the car. A person driving takes up more room than a person walking or using transit, so dense environments, which had once facilitated transportation, became congested instead. As people acquired cars they moved to places that were less dense, and where the urban form could still be molded to accommodate a driving public (Glaeser 2003). Thus dense areas lost population relative to caroriented areas where people could live at more moderate densities. Los Angeles and San Jose were strongly influenced by these forces.

As density increases so too does congestion, in part because it is hard to add more street space in areas that are already heavily developed. Most new lane mileage is instead built on the urban fringe. To the extent that cities try to have their lane mileage keep pace with increasing density, they do so through street widening ordinances, which are often called highway dedication laws. The Los Angeles highway dedication law, for example, requires that existing streets be widened in front of any new multifamily dwellings or apartment buildings (Los Angeles Municipal Code, Section 12.37). 


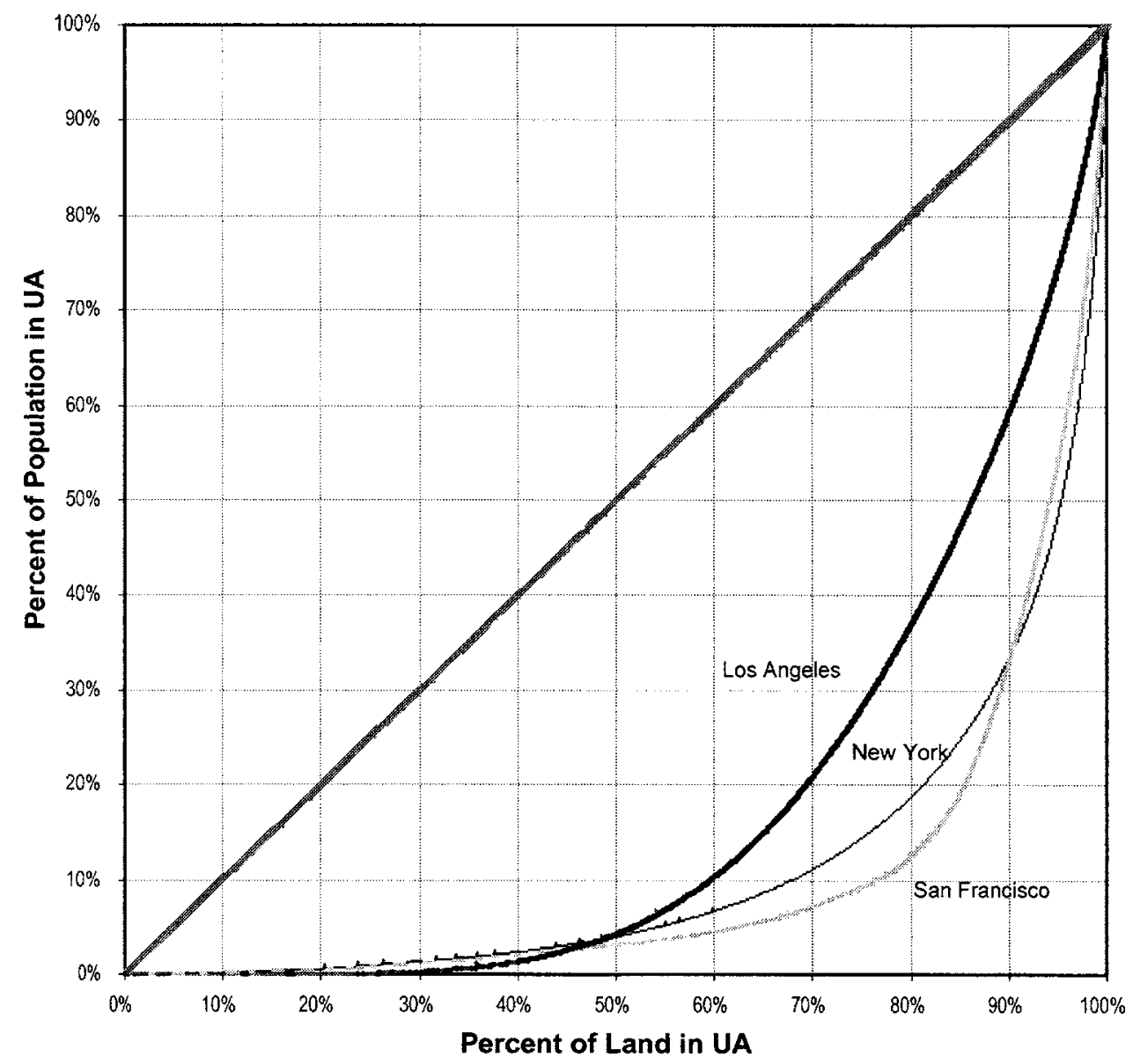

Fig. 1. Population distribution in the Los Angeles, San Francisco, and New York urbanized area

There are good reasons not to like highway dedication laws. Laws that demand wider streets as a condition of increased density quietly subsidize driving, and do so at the expense of other modes. A wider street usually means a narrower sidewalk, or the loss of street trees that once separated pedestrians and vehicles. The law also shifts the costs of driving away from the drivers and onto the developers and tenants of new properties.

Minimum parking requirements function in much the same manner, and on much the same logic, as street dedication laws. The problem of congested curb parking has the same source as the problem of congested roads: absent or inaccurate prices that fail to regulate the competition for scarce space. The solution the laws offer is also similar: in lieu of increasing the price, increase the available space. Like street dedication laws, parking requirements are a hidden mechanism for subsidizing the automobile. Unlike street widening laws, however, parking requirements apply to all new development and demand much more space. The result is a regulatory framework that requires the amount of parking to vary more closely with density than does the amount of street space. In fact, because many parking requirements are designed to meet the maximum possible occupancy of a given land use, the provision of parking, unlike that of streets, could in many areas outstrip the growth of VMT. Increased levels of VMT and parking and static levels of lane mileage translate into an increased ability to store cars but a declining capacity to move them-a combination that makes congestion worse. At the same time, the mandated provision of parking, while exacerbating congestion (a negative externality of density), can also diminish den- sity's positive impacts, such as increased ease of walking and vivacious street life.

\section{Problems with Minimum Parking Requirements}

Although all cities have elaborate sets of parking requirements in their zoning ordinances, no city we are aware of keeps careful track of its total number of parking spaces. The absence of such data makes a direct comparison of parking and streets difficult. However, many cities do collect data on the parking supplies of the central business districts, and we can use the CBD data to illustrate the powerful effects that parking requirements have on the city.

In their classic text The Urban Transportation Problem, John Meyer, John Kain, and Martin Wohl (1965) calculated that in a downtown with 40-ft-wide streets and 12 blocks to the mile, streets would account for $18 \%$ of total land area. Parking, however, could take up much more land. Meyer, Kain, and Wohl calculated that if all commuters traveled downtown by car, and that if all parking was in four-level garages, parking spaces would consume about $38 \%$ of the total land area-more than twice the area taken up by streets. Why would so much more land be needed for parking, even if it was stacked in four-level garages? We tend to think of the land needed by cars as being exclusively a matter of space, but in truth it is a function of space and time. Eric Bruun and Vukan Vuchic (1995) explain that the land used 
by a vehicle is the product of the land area it occupies and the time it occupies it (space used=land area $\times$ time of occupation), and this equation helps explain the enormous demands made by parking on the built environment.

Because of the distance needed between vehicles when they are moving in traffic, cars take up more space when they are being driven than when they are parked. But a car in motion also occupies a given amount of space for only a short time, while a car that is parked takes up slightly less room for a much longer period. For this reason the cumulative space and time consumed by an average vehicle trip is much smaller than the space and time consumed by most parking durations. In one of the first estimates of the "area hours" of land occupied for vehicles for a specific trip, André Schmider (1977) calculated that for a $4 \mathrm{~km}$ round trip with an $8 \mathrm{~h}$ stay at the destination, an automobile traveling $40 \mathrm{~km} / \mathrm{h}$ used $9.6 \mathrm{~m}^{2} \mathrm{~h}$ (the area occupied while moving in traffic multiplied by a 6 min travel time) in motion, and $64 \mathrm{~m}^{2} \mathrm{~h}$ while parked (the area of the parking space multiplied by the eight hour parking duration). Parking therefore used 6.7 times as many meter hours as did travel to and from the destination. Simply put, cars require a lot of land for parking not because parking spaces are big, but because cars are parked so much of the time.

The space that parking requires can be problematic in any part of a city, but it poses particular problems in central business districts. A CBD thrives on high density because its prime advantage over other parts of a metropolitan area is proximity-the immediate availability of a wide variety of activities. The clustering of museums, theaters, restaurants, and offices is the commodity a downtown can offer that other areas cannot (Jacobs 1961; Voith 1998). The automobile jeopardized the CBD's advantage, both because it rendered proximity between some land uses unnecessary, and because the density that made the CBD healthy also made it unsuitable for driving (Bottles, 1987; Fogelson 2002; Jakle and Sculle 2004). For downtowns, the challenge of the auto age has been to accommodate the automobile enough to maintain their vitality, but not so much that they become paralyzed by congestion. One way to strike this balance is to require off-street parking spaces. Off-street parking can reduce the cruising for parking that often chokes the streets of CBDs, and it can make the CBD more accessible to those who would drive into it. But parking requirements are not a strategy that comes without costs. “Abundant, inexpensive parking," Richard Voith (1998, pp. 4 and 5) argues, "would make the CBD more attractive if it had no other consequences; however, plentiful low-cost parking may be at odds with the very aspect that makes a downtown area uniquehigh density."

Parking lots can undermine a CBD's success. A downtown surface lot often has a very high and very visible opportunity cost. Instead of a building teeming with people, there is an expanse of asphalt with a single employee manning a booth; where there could be something there is instead not much. Aesthetically, surface parking is boring and predictable, and disrupts the sense of depth and perspective (what architectural historian Christine Boyer (1997) calls the "city tableaux") that makes an urban area visually compelling. But even when it is dressed up or hiddenwhen it is placed underground, or in a structure that has retail uses at the street level-required off-street parking can still be inimical to density. Because land tends to be most expensive in the CBD, off-street parking is also most expensive there, and constructing it uses up capital that could otherwise be invested more productively. More important, if zoning requires off-street parking, as it does in many cities, then it becomes rational for firms to locate in places where land is less expensive. A parking requirement that is applied uniformly across a city, in other words, implicitly discriminates against development in the $\mathrm{CBD}$, because the burden of complying with the requirement is greater in the $\mathrm{CBD}$ than it is almost anywhere else.

The impacts of parking requirements become clearer when we look at the regulations of New York, San Francisco, and Los Angeles. New York and San Francisco have strict limits on how much parking is allowed in their CBDs. Los Angeles, however, pursues a diametrically opposing path-where the other two cities limit off-street parking, LA requires it. This not only makes development in downtown Los Angeles less attractive than development in other parts of the region, but can also distort the incentives for people traveling into and around the CBD. Consider the parking requirements for a downtown convention center in Los Angeles and San Francisco. Los Angeles requires, as a minimum, fifty times more parking spaces than San Francisco allows as its maximum. The Moscone Convention center, in downtown San Francisco, has 700,000 square feet of exhibit space, 123,000 square feet of "pre-function" space, and no parking spaces. The Los Angeles Convention Center, in downtown Los Angeles, has 770,000 square feet of exhibit space, 54 meeting rooms, and 5,600 on-site parking spaces. The Moscone Center anchors a redevelopment area in San Francisco. The LA Convention Center is surrounded by an ocean of parking.

Another striking example is the different treatment given by Los Angeles and San Francisco to their symphony halls. The home of the San Francisco Symphony, Louise Davies Hall, has very little parking; the city-operated Performing Arts garage, which was built to serve both Davies Hall and the nearby Opera House, has 618 spaces. By contrast Disney Hall, the new home of the Los Angeles Philharmonic, was a parking garage before it was anything else. Its 2,188-space parking structure was built seven years before the 2,265-seat hall itself.

The six-level underground garage cost $\$ 110$ million to build, or about $\$ 50,000$ per space. Financially troubled Los Angeles County, which built the structure, went into debt to finance it, and justified the move by arguing that parking revenues would repay the borrowed money. But the parking structure was completed in 1996, and Disney Hall, which suffered from a budget less grand than its vision, became knotted in delays and didn't open until late 2003. During the seven years in between, parking revenue fell far short of debt payments and the county, by that point nearly bankrupt, had to subsidize the garage even as it laid employees off (Fulton 2001). The county owns the land Disney Hall sits on, and when the hall finally opened the county required that the hall schedule at least 128 performances each winter season. This requirement had nothing to do with the perceived adequacy of LA's cultural offerings; the county needed to pay debt service on the garage, and 128 was the minimum number of performances that its analysts said would generate the revenue needed to do that. And so in its first year the hall scheduled exactly 128 performances. The parking lot was designed to serve the symphony, but for the foreseeable future the symphony has been re-oriented to pay for the parking lot. The minimum parking requirements have led to a minimum concert requirement.

The parking requirements for Disney Hall shifted resources toward cars and away from other, arguably more important aspects of the project, such as its design. Disney Hall's architect, Frank Gehry, had originally envisioned limestone as the material for the building's exterior, but when the project began to sag under financial difficulties the plans were changed, and to save money the hall was clad in cheaper stainless steel. This was not, in and of itself, a huge problem. Although one could argue that 
the hall would look better in limestone, it is still, even sheathed in steel, quite stunning, and has opened to wide accolades from both the public and the architectural community.

The parking structure also cannot be entirely blamed for the hall's financial woes, which were many and varied. But the money spent on parking altered the hall in other ways as well, orienting its design toward drivers and away from pedestrians. The presence of a six-story underground garage means that most concert patrons arrive from beneath, rather than outside, the hall. The hall's designers clearly understood this, and so while Disney Hall has an impressive street entrance, its more magisterial gateway is a vertical one: an "escalator cascade" that flows up from the parking structure and ends in the foyer. This has profound implications for street life. A concertgoer can now drive to Disney Hall, park beneath it, ride up into it, attend a concert, and then reverse the whole process-and never set foot on a sidewalk in downtown LA. The full experience of an iconic Los Angeles building begins and ends in its garage, not in the city itself.

Visitors to downtown San Francisco are unlikely to have such a privatized and encapsulated experience. Even the short walk from the Performing Arts garage puts people on the street, and many theater patrons also park at private lots somewhat farther away, meaning that they walk by the shops and restaurants of the Hayes Valley neighborhood. Although the absence of parking requirements will not automatically create a vibrant downtownthe area around Davies Hall is not terribly lively (although the area around North Beach, where several other theaters are located, is very lively indeed) — their presence will almost certainly inhibit one, for the simple reason that parking requirements can prevent human interaction with the street.

The idea that a downtown designed to accommodate cars also stifles pedestrian life is not a new one, and many researchers and advocates, perhaps most vocally the New Urbanists, have detailed the tension between walking environments and parking environments (Duany et al. 2000). Parking lots make walking more hazardous and less enjoyable, because they force pedestrians to dodge cars that slide out of underground structures, or to cross featureless terrains where buildings are set far back from the street. All this serves to alienate pedestrians and sterilize street life. "The more a downtown gets broken up and interspersed with parking lots," Jane Jacobs (1961, p. 19) wrote, "the duller and deader it becomes. And there is nothing more repellent than a dead downtown."

\section{Human Density and Parking Density}

Disney Hall is a notable but not exceptional example of urbanism in downtown Los Angeles. Throughout the LA CBD-and particularly its newer, northern section that is the product of urban renewal-one can find stunning buildings that are largely selfcontained. The Central Library has its own massive underground garage. Across Flower Street from the library are the Arco Towers, which have not only a subterranean garage and a separate above-ground parking structure, but also a seven acre underground mall with shops, restaurants, a gym and a post office. Employees in Arco Plaza can arrive at work, run errands during the day, work out at the gym, and then go home, having never ventured outside. If they do decide to step out, it is just a short walk to an enclosed, elevated walkway that will carry them into the Bonaventure Hotel, which also sits astride a voluminous parking garage. The elevated walkway is in fact one of the few ways
Table 4. CBD Land Areas in Streets and Parking in the 1960s

\begin{tabular}{|c|c|c|c|c|c|c|}
\hline $\begin{array}{l}\text { Central business } \\
\text { district }\end{array}$ & Year & $\begin{array}{l}\text { Total } \\
\text { acres }\end{array}$ & $\begin{array}{l}\text { Percent in } \\
\text { streets }\end{array}$ & Rank & $\begin{array}{l}\text { Percent in } \\
\text { parking }\end{array}$ & Rank \\
\hline Los Angeles & 1960 & 400 & 35 & 5 & 24 & 1 \\
\hline Dallas & 1961 & 344 & 35 & 8 & 18 & 2 \\
\hline $\begin{array}{l}\text { Winston-Salem, } \\
\text { N.C. }\end{array}$ & 1961 & 334 & 25 & 13 & 15 & 3 \\
\hline Minneapolis & 1958 & 580 & 35 & 7 & 14 & 4 \\
\hline $\begin{array}{l}\text { Chattanooga, } \\
\text { Tenn. }\end{array}$ & 1960 & 246 & 22 & 14 & 13 & 5 \\
\hline $\begin{array}{l}\text { St. Paul, } \\
\text { Minn. }\end{array}$ & 1958 & 482 & 33 & 9 & 11 & 6 \\
\hline Detroit & 1953 & 690 & 39 & 2 & 11 & 7 \\
\hline Chicago & 1956 & 678 & 31 & 10 & 10 & 8 \\
\hline $\begin{array}{l}\text { Charlotte, } \\
\text { N.C. }\end{array}$ & 1958 & 473 & 29 & 12 & 10 & 9 \\
\hline $\begin{array}{l}\text { Tucson, } \\
\text { Ariz. }\end{array}$ & 1960 & 128 & 35 & 4 & 8 & 10 \\
\hline $\begin{array}{l}\text { Columbus, } \\
\text { Ohio }\end{array}$ & 1955 & 502 & 40 & 1 & 8 & 11 \\
\hline $\begin{array}{l}\text { Sacramento, } \\
\text { Calif. }\end{array}$ & 1960 & 350 & 35 & 6 & 7 & 12 \\
\hline
\end{tabular}

Note: Source $=$ Wilbur Smith \& Associates (1966).

to enter the Bonaventure, as most of its sidewalk level walls are doorless and windowless.

These underground garages and vertical parking structures have a deceptively powerful influence on how downtown Los Angeles works. In 1966, planning consultant Wilbur Smith assembled data on streets and parking in a number of American CBDs. Table 4 shows his results. In its share of land devoted to streets, Los Angeles was approximately $35 \%$, just 2.29 percentage points above the mean for the 12-city group. In its area devoted parking, however, it easily outdistanced all other cities, with $24 \%$ of its downtown given over to the storage of cars, versus a $12 \%$ average for all cities combined. Of this $24 \%, 21 \%$ was in surface parking, and only three percent was in parking structures (Smith 1965 , p. 60). Since the LA data were gathered in 1960, this prevalence of surface lots may, again, reflect the impact of urban renewal and demolition to avoid property taxes. In an earlier study Smith had worried that the future development of Bunker Hill would deprive the LA CBD of parking spaces (Smith 1965, p. 91).

Today the Los Angeles CBD looks much different. Bunker Hill is largely built out, and high-rise buildings gleam where parking lots once sat. Viewed from the air, or from a street grid, downtown LA does not look very different than other American city centers. But it would be inaccurate to say that parking has been replaced by people. The parking in downtown LA is now better hidden, but it is far from gone. In fact, what makes the Los Angeles CBD unique is its high parking density. Table 5 is derived from transportation data that Jeffrey Kenworthy and Felix Laube (1999) provide for 44 world cities. Columns 2 and 3 show the land area (in hectares) and number of parking spaces in each city's CBD, and Column 4 shows the number of parking spaces per hectare. Many of the parking spaces in CBDs are in vertical or underground structures, but for the sake of illustration Column 5 shows how much land each CBD's spaces would occupy if they were spread horizontally over a surface lot. The 107,441 spaces in the Los Angeles CBD would cover 331 hectares of land, or $81 \%$ of the CBD's total land area of 408 hectares. This ratio, of parking area to land area, can be called the "parking coverage" 


\begin{tabular}{|c|c|c|c|c|c|c|c|c|c|}
\hline City & (1) & $\begin{array}{c}\text { Land area } \\
\text { (hectares) } \\
(2)\end{array}$ & $\begin{array}{c}\text { Parking } \\
\text { spaces } \\
(3)\end{array}$ & $\begin{array}{l}\text { Parking spaces } \\
\text { per hectare } \\
(4)=(3) /(2)\end{array}$ & $\begin{array}{c}\text { Parking area }{ }^{a} \\
\quad \text { (hectares) } \\
(5)=(3) / 325\end{array}$ & $\begin{array}{c}\text { Parking } \\
\text { coverage } \\
(6)=(5) /(2)\end{array}$ & $\begin{array}{c}\text { Employment } \\
\text { (jobs) } \\
\text { (7) }\end{array}$ & $\begin{array}{c}\text { Jobs per } \\
\text { hectare } \\
(8)=(7) /(2)\end{array}$ & $\begin{array}{c}\text { Parking spaces } \\
\text { per job } \\
(9)=(3) /(7)\end{array}$ \\
\hline 1 & Los Angeles & 408 & 107,441 & 263 & 331 & $81 \%$ & 206,474 & 506 & 0.52 \\
\hline 2 & Melbourne, Australia & 172 & 42,601 & 248 & 131 & $76 \%$ & 126,286 & 734 & 0.34 \\
\hline 3 & Adelaide, Australia & 181 & 42,857 & 237 & 132 & $73 \%$ & 73,868 & 408 & 0.58 \\
\hline 4 & Houston & 392 & 72,797 & 186 & 224 & $57 \%$ & 118,889 & 303 & 0.61 \\
\hline 5 & Detroit & 362 & 65,639 & 181 & 202 & $56 \%$ & 93,012 & 257 & 0.71 \\
\hline 6 & Washington, D.C. & 460 & 80,100 & 174 & 246 & $54 \%$ & 316,723 & 689 & 0.25 \\
\hline 7 & Brisbane & 117 & 19,895 & 170 & 61 & $52 \%$ & 61,844 & 529 & 0.32 \\
\hline 8 & Calgary, Atl., Canada & 298 & 45,260 & 152 & 139 & $47 \%$ & 86,700 & 291 & 0.52 \\
\hline 9 & Portland, Ore. & 280 & 41,861 & 150 & 129 & $46 \%$ & 103,872 & 371 & 0.40 \\
\hline 10 & Brussels, Belgium & 308 & 45,512 & 148 & 140 & $45 \%$ & 144,906 & 470 & 0.31 \\
\hline 11 & Vancouver, B.C., Canada & 337 & 46,053 & 137 & 142 & $42 \%$ & 104,000 & 309 & 0.44 \\
\hline 12 & Edmonton, Alt., Canada & 297 & 37,512 & 126 & 115 & $39 \%$ & 63,200 & 213 & 0.59 \\
\hline 13 & Frankufurt, Germany & 240 & 29,487 & 123 & 91 & $38 \%$ & 119,735 & 499 & 0.25 \\
\hline 14 & Canberra, Australia & 329 & 39,558 & 120 & 122 & $37 \%$ & 22,521 & 68 & 1.76 \\
\hline 15 & Chicago & 395 & 46,653 & 118 & 144 & $36 \%$ & 363,794 & 921 & 0.13 \\
\hline 16 & Denver & 636 & 37,757 & 107 & 208 & $33 \%$ & 93,012 & 146 & 0.73 \\
\hline 17 & San Francisco & 391 & 39,756 & 102 & 122 & $31 \%$ & 291,036 & 744 & 0.14 \\
\hline 18 & Toronto & 188 & 18,436 & 98 & 57 & $30 \%$ & 174,267 & 927 & 0.11 \\
\hline 19 & Sydney, Australia & 416 & 39,031 & 94 & 120 & $29 \%$ & 175,620 & 422 & 0.22 \\
\hline 20 & San Diego & 570 & 50,234 & 88 & 155 & $27 \%$ & 72,964 & 128 & 0.69 \\
\hline 21 & Winnipeg, Canada & 440 & 37,419 & 85 & 115 & $26 \%$ & 68,593 & 156 & 0.55 \\
\hline 22 & Boston & 868 & 73,604 & 85 & 226 & $26 \%$ & 119,189 & 137 & 0.62 \\
\hline 23 & Ottawa & 305 & 25,565 & 84 & 79 & $26 \%$ & 111,031 & 364 & 0.23 \\
\hline 24 & Perth, Wash. & 759 & 63,000 & 83 & 194 & $26 \%$ & 99,819 & 132 & 0.63 \\
\hline 25 & Phoenix & 393 & 31,937 & 81 & 98 & $25 \%$ & 35,267 & 90 & 0.91 \\
\hline 26 & Montreal & 1,224 & 94,745 & 77 & 292 & $24 \%$ & 273,203 & 223 & 0.35 \\
\hline 27 & Paris & 2,333 & 172,000 & 74 & 529 & $23 \%$ & 862,180 & 370 & 0.20 \\
\hline 28 & Munich, Germany & 795 & 58,430 & 73 & 180 & $23 \%$ & 219,518 & 276 & 0.27 \\
\hline 29 & Vienna, Austria & 298 & 21,036 & 71 & 65 & $22 \%$ & 112,770 & 378 & 0.19 \\
\hline 30 & Singapore & 725 & 45,870 & 63 & 141 & $19 \%$ & 280,000 & 386 & 0.16 \\
\hline 31 & Copenhagen, Denmark & 455 & 27,400 & 60 & 84 & $19 \%$ & 122,770 & 270 & 0.22 \\
\hline 32 & Sacramento, Calif. & 462 & 27,677 & 60 & 85 & $18 \%$ & 54,121 & 117 & 0.51 \\
\hline 33 & New York & 2,331 & 138,148 & 59 & 425 & $18 \%$ & $2,305,545$ & 989 & 0.06 \\
\hline 34 & Hamburg, Germany & 460 & 27,056 & 59 & 83 & $18 \%$ & 152,590 & 332 & 0.18 \\
\hline 35 & Zurich, Switzerland & 152 & 8,668 & 57 & 27 & $18 \%$ & 63,410 & 417 & 0.14 \\
\hline 36 & Hong Kong & 113 & 6,376 & 56 & 20 & $17 \%$ & 193,520 & 1,713 & 0.03 \\
\hline 37 & Kuala Lampur & 1,625 & 86,030 & 53 & 265 & $16 \%$ & 290,000 & 178 & 0.30 \\
\hline 38 & London & 2,697 & 138,843 & 51 & 427 & $16 \%$ & $1,142,781$ & 424 & 0.12 \\
\hline 39 & Amsterdam & 824 & 28,600 & 35 & 88 & $11 \%$ & 80,722 & 98 & 0.35 \\
\hline 40 & Stockholm & 424 & 13,050 & 31 & 40 & $9 \%$ & 111,233 & 262 & 0.12 \\
\hline 41 & Seoul, Korea & 2,117 & 59,758 & 28 & 184 & $9 \%$ & $1,226,830$ & 580 & 0.05 \\
\hline 42 & Bangkok & 2,056 & 50,848 & 25 & 156 & $8 \%$ & 271,944 & 132 & 0.19 \\
\hline 43 & Tokyo & 4,208 & 98,755 & 23 & 304 & $7 \%$ & $2,300,728$ & 547 & 0.04 \\
\hline \multirow[t]{2}{*}{44} & Manila & 3,600 & 22,000 & 6 & 68 & $2 \%$ & 815,400 & 227 & 0.03 \\
\hline & Average & 828 & 53,074 & 100 & 163 & $31 \%$ & 321,043 & 403 & 0.36 \\
\hline
\end{tabular}

Note: Source for CBD area and parking spaces: Kenworthy and Laube (1999, Chapter 3).

${ }^{\text {a }}$ Total parking area is the surface parking area (hectares) that all parking spaces (column 3) would occupy. Each hectare of surface parking accommodates about 325 parked cars.

rate, and LA's is, to our knowledge, the highest on earth. Melbourne, the city with the next-highest rate, registers at $76 \%$, while at the lower end we find New York (18\%), London (16\%), and Tokyo $(7 \%)$.

To some extent the parking coverage rate speaks to the amount of space devoted to the car in downtown Los Angeles. But a closer look at the table shows that this seemingly straightforward measure, like the "share of land in streets" is not so straightforward after all. The coverage rate itself, though an eye-catching number, is less important than the interaction between the density of jobs and the number of parking spaces per job (parking density). Consider the CBDs of Phoenix, San Francisco, and Los 
Table 6. Land, Jobs, and Parking in Three CBDs

\begin{tabular}{lrrr}
\hline & Phoenix, Ariz. & San Francisco & Los Angeles \\
\hline CBD area (hectares) & 393 & 391 & 408 \\
CBD parking spaces & 31,937 & 39,756 & 107,441 \\
CBD jobs & 35,267 & 291,036 & 206,474 \\
Jobs/hectare & 90 & 744 & 506 \\
Parking spaces/1,000 jobs & 910 & 140 & 520 \\
Parking spaces per hectare & 81 & 102 & 263 \\
Parking coverage rate $(\%)$ & 25 & 31 & 81 \\
\hline
\end{tabular}

Angeles, all of which are about the same size (roughly 400 hectares, or 1,000 acres). An obvious anomaly pops up: Phoenix, which most people would assume to be the most autooriented of the three, has the lowest parking coverage rate $(25 \%)$. The explanation for this lies not in Phoenix's relative absence of parking spaces, but its relative absence of jobs. Phoenix has the highest number of parking spaces per job (0.91), but the fewest number of jobs (90 per hectare). It has a lot of parking for relatively few people, and for this reason many commuters to the Phoenix CBD drive alone to work.

In San Francisco we find the reverse situation: a lot of people and relatively little parking per job-a function of the zoning ordinance that limits the number of parking spaces in the CBD. San Francisco, like Phoenix, has a low parking coverage rate (31\%) but for a very different reason. Where Phoenix's low coverage rate is driven by its low job density, San Francisco's is driven by its relative refusal to accommodate the car (through its laws that limit parking).

Los Angeles is different from both Phoenix and San Francisco (Table 6, Fig. 2). LA has three times as many parking spaces as Phoenix, but over five times as many jobs. The high employment density in Los Angeles (506 jobs per hectare, as compared to Phoenix's 90) gives it many fewer parking spaces per job $(0.52$ compared to 0.91). Next to San Francisco, however, Los Angeles has fewer jobs but more than twice as many parking spaces. San Francisco has $47 \%$ more jobs per hectare but $74 \%$ fewer parking spaces per job: its parking supply, of roughly 40,000 spaces, is less than half that of LA's. Los Angeles is both car-oriented and dense; it approaches the human density of San Francisco but dilutes it with the parking supply of a suburb. Many benefits it might derive from its density are offset by its relentless accommodation of the automobile.

Los Angeles is dense and getting denser, and as long as accommodating the car remains a primary focus of its development

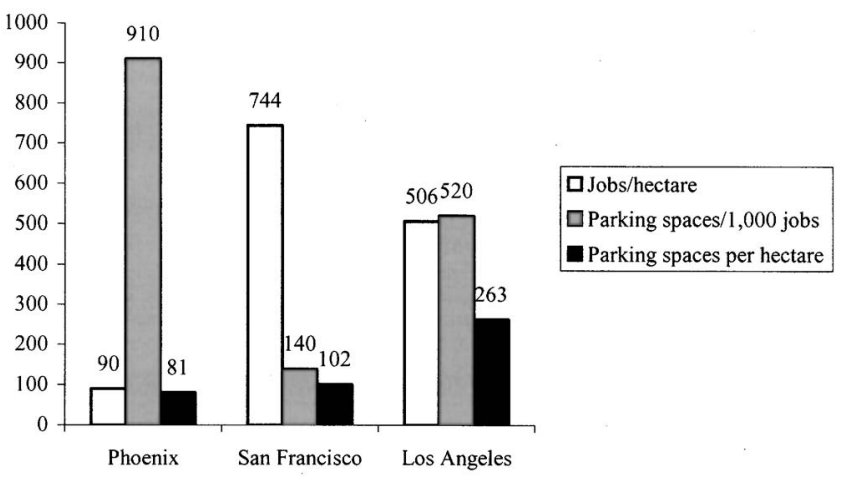

Fig. 2. Land, jobs, and parking in Phoenix, San Francisco, and Los Angeles regulations, this increasing density will be a problem rather than a solution. With off-street parking requirements, increases in density simply bring more cars, more congestion, and more air pollution, to say nothing of increased disruptions in the urban fabric and more money redirected away from buildings and toward cars. In New York and San Francisco, the accommodation of the car varies inversely with density. Twenty-nine percent of San Francisco's households have no car, as opposed to only 7\% of its households in the suburbs. In Manhattan the discrepancy is even greater: $78 \%$ of households have no car, while in the rest of the New York region only $7 \%$ of households go carless (McGuckin and Srinivisan 2003).

In Los Angeles, minimum parking requirements inhibit density's ability to make driving more expensive or less attractive. We should not overstate our case; parking requirements do not create all parking lots, and they did not initiate the provision of parking in CBDs. The erosion of American downtowns by parking lots began as a rational market response to high taxes and falling land values. But as urban historians John Jakle and Keith Sculle have noted, these taxpayer parking lots were expected to be "entirely transitory"- a foreshadowing of future development rather than an enduring facet of the urban landscape. The arrival of parking requirements, however, perpetuated and exacerbated the surplus of parking that tax avoidance and urban renewal had begun. Parking was transformed from a product of market circumstances into a product of municipal law. This was in some ways a pathdependent process, but it was not an inevitable one. It was and is within cities' powers to prevent the spread of parking lots; most cities just choose not to do so. An exception is downtown San Francisco, where surface parking lots are transitory by law; if a building is demolished and the vacant land converted to a parking lot, the parking lot can only operate for two years (San Francisco Planning Code, Section 156d).

\section{Conclusion}

The interplay of population density and the share of land devoted to automobiles is more complex than advocates and even many academics suggest. Of all the automobile infrastructure in an urban region, parking is the most dynamically supplied. Urban highways, even in their heyday, were infrequently built; today they are barely built at all. Streets are constructed more often, particularly in fast-growing areas, but the amount of road space in cities, and especially their cores, does not change very much. Parking, however, is constructed on a regular basis. In most cities new development is contingent on the creation of new parking, and so although all cities have a shortage of streets and freeway space - at least according to traffic management standards - many have a surplus of parking (Schrank and Lomax, 2004; Shoup 2005).

The surplus arises because parking is an automatic aspect of the planning process. The construction of a new highway is often marked by protest, litigation, fanfare, rent-seeking, public input, and litigation. Parking, more often than not, is just quietly built, and a fair case can be made that in many instances it does more harm than good. We are not the first to make such an argument: Jane Jacobs called parking lots "border vacuums"-dead spaces that divided lively areas from each other, and unraveled a city's sense of urbanity. Lewis Mumford (1961, p. 23), who disagreed with Jacobs on many counts, concurred with her on the pernicious effects of parking. "The right to access every building in the city by private motorcar," he wrote, "in an age when everyone owns 
such a vehicle, is actually the right to destroy the city." Mumford meant not physical destruction, of course, but destruction of the interdependence that makes the buildings in a CBD more than the sum of their parts. Parking requirements go a long way toward making a CBD little more than a group of buildings, each a destination in its own right, to be parked at and departed from, and not part of some larger whole.

Perhaps the simplest and most productive reform of American zoning would be to declare that all existing off-street parking requirements are maximums rather than minimums. The examples of New York and San Francisco suggest that limits on off-street parking can foster many of density's benefits, and urbanists who admire these cities might urge other places to adopt their approaches to parking. From a different perspective, however, more regulation may not be the best first step. The market can mediate the supply of parking in most urban areas, and despite the planner's frequent desire to replace a floor with a ceiling, it may be better to simply deregulate parking - to force it on no one and let those who want it pay for it. A market-oriented approach to parking would eliminate cumbersome regulations, remove incentives to drive, and let city planners concentrate on matters that seriously demand their attention.

\section{Acknowledgments}

The writers would like to thank Eran Ben-Joseph and an anonymous referee for valuable comments, as well as Dave King, Paul Sorensen, Anne MacAulay, Eric Morris, Paul Philley, George Kosovich, and Bruce Williamson. Participants in a session at the ACSP Conference in Portland, Ore., in October 2004 also made helpful suggestions.

\section{References}

Akbari, H., Rose, L. S., and Tara, H. (2003). "Analyzing the land cover of an urban environment using high-resolution orthophotos." Landsc. Urban Plann., 63, 1-14.

Berehndt, W. C. (1940). "Off-street parking: A city planning problem." J. Land and Public Utility Economics, 16(4), 464-468.

Best, J. (2001). Damned lies and statistics, University of California Press, Berkeley, Calif.

Borchert, J. (1982). Alley life in Washington, University of Chicago Press, Chicago.

Bottles, S. (1987). Los Angeles and the automobile, University of California Press, Berkeley, Calif., and Los Angeles.

Boyer, M. C. (1997). The city of collective memory, MIT Press, Cambridge, Mass.

Bruun, E., and Vuchic, V. (1995). "Time-area concept: Development, meaning, and applications." Transportation Research Record 1499, Transportation Research Board, Washington, D.C., 95-104.

Davis, M. (1998). Ecology of fear, Vintage, New York.

Duany, A., Playter-Zyberk, E., and Speck, J. (2000). Suburban nation, North Point Press, New York.

Ewing, R. (1997). "Is Los Angeles-style sprawl desirable?" J. Am. Plan. Assn., 63(1), 107-126.

Fogelson, R. (2002). Downtown: Its rise and fall, Yale University Press, New Haven, Conn.

Fulton, W. (2001). The reluctant metropolis: The politics of growth in Los Angeles, Johns Hopkins, Baltimore, Md.

Fulton, W., Pendall, R., Nguyen, M., and Harrison, A. (2001). Who sprawls most? How growth patterns differ across the U.S., Brookings Institution, Washington, D.C.
Glaeser, E. (2003). "Reinventing Boston: 1640-2003." Working Paper 10166, National Bureau of Economic Research, (www.nber.org/ papers/w10166〉 (Aug. 15, 2004).

Hanson, M. (1992). "Automobile subsidies and land use." J. Am. Plan. Assn., 58(1), 60-72.

Jacobs, J. (1961). The death and life of great American cities, Vintage, New York.

Jakle, J., and Sculle, K. (2004). Lots of parking: Land use in a car culture, University of Virginia Press, Charlottesville, Va.

Kantor, P. (1987). The dependent city, Scott, Foresman, New York.

Kenworthy, J., and Laube, F. (1999). An international sourcebook of automobile dependence in cities, 1960-1990, University Press of Colorado, Boulder, Colo.

King, J. (1969). "The art of city building." Centuiry City Centurion, special supplement to the Los Angeles Times March 10, p. 10.

Marchand, B. (1986). The emergence of Los Angeles, Pion, London.

Markusen, A., Hall, P., Campbell, S., and Deitrick, S. (1991). The rise of the gunbelt, Oxford University Press, New York.

McGuckin, N., and Srinivasan, N. (2003). "Journey to work trends in the United States and its major metropolitan areas." Rep. to the Federal Highway Administration, FHWA-EP-03-058 〈www.fhwa.dot.gov/ ctpp/jtw/index.htm〉 (August 12, 2004).

McPherson, E. G. (1998). “Structure and sustainability of Sacramento's urban forest." J. Aboriculture, 24(4), 174-190.

Meyer, J., and Gómez-Ibáñez, J. (1983). Autos, transit and cities, Harvard University Press, Cambridge, Mass.

Meyer, J., Kain, J., and Wohl, M. (1965). The urban transportation problem, Harvard University Press, Cambridge, Mass.

Mollenkopf, J. (1983). The contested city, Princeton University Press, Princeton, N.J.

Mumford, L. (1961). The city in history, Harcourt Brace, New York.

Myrup, L. O., and Morgan, D. L. (1972). "Numerical model of the urban atmosphere." The city-surface interface, Vol. 1, Dept. of Agricultural Engineering, Dept. of Water, Science and Engineering, Univ. of California, Davis, Calif.

Renner, M. (1988). Rethinking the role of the automobile, World Watch Institute, Washington, D.C.

Ross, C., and Dunning, A. (1997). "Land use and transportation interaction: An examination of the 1995 NPTS data." Searching for Solutions: Nationwide Personal Transportation Survey Symp., Federal Highway Administration, Washington, D.C.

Sale, K. (1980). Human scale, Coward, McCann \& Geohagan, New York.

Schmider, A. (1977). "L'espace urbain, Un bien public," Metropolis, January, 55-57.

Schrank, D., and Lomax, T. (2004). Urban Mobility Rep., Texas Transportation Institute, Texas A\&M Univ. 〈http://tti.tamu.edu/product/ catalog/reports/mobility_report_2004.pdf $\rangle$

Shoup, D. (2005). The high cost of free parking, Planner's Press, Chicago.

Sierra, Club. (1998). "Sprawl: The dark side of the American dream." 〈www.sierraclub.org/sprawl/report98/what.html〉 (Oct. 10, 2004).

Smith, W. (1965). "Parking in the city center." Report prepared for the Automobile Manufacturer's Association of America, New Haven, Conn.

Southworth, M., and Ben-Joseph, E. (1996). Streets and the shaping of towns and cities, McGraw-Hill, New York.

Southworth, M., and Owens, P. (1993). "The evolving metropolis." J. Am. Plan. Assn., 59(3), 279-281.

Taylor, S. (1959). "Freeways alone are not enough.” Traffic Q., July, 346-365.

Voith, R. (1998). "The downtown parking syndrome: Does curing the illness kill the patient?" Federal Reserve Bank of Philadelphia Business Review, January/February, 3-14. 〈www.phil.frb.org/files/br/ brjf98dv.pdf $\rangle$

Wilbur Smith and Associates (1966). Transportation and parking for tomorrow's cities; Report prepared for the Automobile Manufacturer's Association of America, 59, New Haven, Conn. 